\title{
Dysfunction and pain temporomandibular disorder caused by impeded eruption of third mandibular molars
}

\author{
Magdalena Bakalczuk', Andrzej Bożyk², Ingrid Różyło-Kalinowska ${ }^{3}$, Elżbieta Kobyłecka \\ Jacek Szkutnik' \\ ${ }^{1}$ Department of Functional Masticatory Disorders, Medical University Lublin, Poland \\ ${ }^{2}$ Department of Dental Prosthetics, Medical University, Lublin, Poland \\ 3 Independent Unit of Propedeutics of Dental and Maxillofacial Radiology, Medical University, Lublin, Poland \\ ${ }^{4}$ Department of Mathematics and Medical Biostatistics, Medical University, Lublin, Poland
}

Bakalczuk M, Bożyk A, Różyło-Kalinowska I, Kobyłecka E, Szkutnik J. Dysfunction and pain temporomandibular disorder caused by impeded eruption of third mandibular molars. J Pre-Clin Clin Res. 2014; 8(2): 100-102. doi: 10.5604/18982395.1135659

\section{Abstract}

Introduction. There are reports in literature which indicate the connection between impacted third molars and occurrence of symptoms of craniomandibular dysfunctions and headaches.

Objectives. The aim of this study was evaluation of the outcome of patients who reported specific symptoms of craniomandibular dysfunction and had impacted mandibular third molars.

Materials and method. The research material consisted of 10 women who reported to the Department of Craniomandibular Disfunctions of the Medical University in Lublin, Poland, with pain and acoustic symptoms in the Temporomandibular joint (TMJ) area. During preliminary therapy, the patients used a silicone occlusal device; ionotherapy was ordered and the patients were recommended to eliminate parafunctions.

Results. Clicks before treatments were present in 6 patients, after treatment with silicone occlusal device and ionotherapy with Profenid gel in 5 patients, while two years after extraction of the impacted teeth the clicks were no longer present, and differences in the presence of clicks analyses by means of the Q-Cochran test were statistically significant between examinations $1 \mathrm{~m}$ vs.3 $(\mathrm{Q}=10.33 ; \mathrm{p}<0.01)$ and examinations 2 vs.3 $(\mathrm{Q}=8.40 ; \mathrm{p}<0.05)$.

Conclusions. The study showed that extraction of the mandibular third molars can cause regression of some symptoms of craniomandibular disorders.

\section{Key words}

temporomandibular region, temporomandibular disorder, third molar extraction

\section{INTRODUCTION}

Temporomandibular disorders (TMD) concern both young and old patients. Data from literature show that since the 1980 s there has been a constant statistically significant growth in the number of patients under the age of 18 who reported for treatment due to TMD, and among the young patients who reported for curing TMD it was as advanced as in adult patients. The average annual number of patients under 18 who reported for treatment due to TMD, according to Litko at al. [1], statistically significantly increased from $6.8 \%$ in $1987-1989$ to $13.4 \%$ in $1990-1999$, and to $23.4 \%$ in 2000-2005. The number of patients under 18 with TMD who need diagnosing and curing can increase in subsequent years. During stress situations there occurs intensification of parafunctions and a decrease in the adaptive possibilities of the stomatognathic system $[1,2]$.

Many authors emphasize the connection of impacted maxillary third molars with headache. Janas at al. [3] described 15 patients with headaches caused by impacted third molars treated unsuccessfully previously by physicians of other specialties, and finally treated by sole surgical extraction of the third molar. It seems important that the

Address for correspondence: Magdalena Bakalczuk, Department of Functional Masticatory Disorders,Medical University of Lublin, Karmelicka 7 (SCK), 20-081 Lublin, Poland

E-mail: magdalena.bakalczuk@wp.eu

Received: 17 October 2014; accepted: 17 November 2014 dental surgeon should be aware of the possible connection between head and neck pains, and an impacted third molar. The quoted authors proved that some dental and maxillofacial illnesses cause pain occurring not in the disease area but in a distant region. This pain is often of a radiating character with shooting and throbbing traits, or it occurs as a constant pain with different intensification [3].

Szyperska at al. [4] described one-year clinical observation of 120 patients who reported for treatment for TMD. During examinations, 52 patients complained of pain during opening and clenching of jaws. Forty-seven patients complained of clicks, the others reported frictions. The patients were treated by means of third molar extraction and mechanotherapy. Four weeks after treatment, regression of the complains were observed, the model of jaw mobility was improved, and symptoms of acoustic (clicks, frictions) symptoms disappeared in temporomandibular joint (TMJ). It is worth noting that in about $42 \%$ patients pain complaints subsided on the day following intervention, and range abduction of the mandible was also improved.

Data from literature shows that the problem of third molars has mainly been analyzed from the aspect of pathology caused by delayed eruption, whereas the influence of third molar presence on TMJ disorders was rarely discussed. Panek et al. [5] found during the examination of 303 patients that the prevalence of TMJ disorders was significantly higher when maxillary and mandibular third molar contacted in centric occlusion. 
Based on a literature review, clinical researches and analysis of the panoramic radiographs of 312 patients aged 18-70 years, it was found that impacted third molar occurred more often in the lower than in the upper jaw. Through panoramic radiograph it is possible to detect impacted third molars and predict the time of their eruption, as well as to make the decision to extract them [6].

\section{OBJECTIVES}

The aim of this study was evaluation of the therapeutic outcome in patients who reported with specific symptoms of craniomandibular dysfunction and had impacted mandibular third molars.

\section{MATERIALS AND METHOD}

The material consisted of 10 women aged 18-28 years who reported with pain and acoustic symptoms in TMJ area to the Department of Craniomandibular Disfunctions at the Medical University in Lublin, Poland. The medical history of each patient was obtained and data recorded concerning age, gender and presence of occlusal and nonocclusal parafunctions of the organ of mastication. The presence of systemic diseases, drug taking, past head and neck trauma and specialist treatment by orthodontist, neurologist, rheumatologist or orthopedic surgeon were noted. There were also examined the range of mandible movement, deviation of these movements from axis symmetry, presence of acoustic symptoms in TMJ, pain symptoms and the intensity of pain measured by means of the VAS scale. Analysis of panoramic radiographs was performed. On the basis of these examinations, ionotherapy with Profenid gel was ordered (10 procedures for each TMJ, lasting 5 minutes at $3 \mathrm{~mA}$ ), and silicone occlusal devices applied in the treatment position of the mandible, determined based on occlusal tests according to Kleinrok [7]. The patients used silicone an occlusal device only during the night. They were recommended to change their nutritional habits, consisting in applying a soft diet and eliminating parafunctions such as gum chewing, and biting of nails or cuticles. A follow-up visit was appointed six weeks later, during which were evaluated the presence and intensity of pain complaints on the VAS scale, acoustic symptoms, lower jaw movements and their deviation from axis of symmetry. After this, extraction of the third molar was recommended to the patients.

The patients were reexamined 2 years later and the same parameters were evaluated. Statistical analysis was also performed using the Friedman and Wilcoxon tests for dependent variables in which measure of central tendency median was used. Quality data were analyzed with the Q-Cochran test in which conformity of the presence of TMJ clicks was compared in the examined groups. Confidence level was set at $\mathrm{p}=0.05$. The results are shown in Tables 1 and 2 .

\section{RESULTS}

Before treatment, all patients had pain complaints in the TMJ area during movements of abduction and adduction of the mandible and during palpation. The patients described the pain as intermittent and concerning either the left or right side.
Table 1. Comparison of symptoms before extraction and after extractions of third molar

\begin{tabular}{|c|c|c|c|c|c|c|}
\hline \multirow[t]{2}{*}{ Patient } & \multicolumn{2}{|c|}{$\begin{array}{c}\text { Symptoms } \\
\text { before treatment } \\
\text { (examination 1) }\end{array}$} & \multicolumn{2}{|c|}{$\begin{array}{l}\text { Symptoms after } \\
\text { treatment with silicone } \\
\text { occlusal device } \\
\text { and ionotherapy } \\
\text { (examination 2) }\end{array}$} & \multicolumn{2}{|c|}{$\begin{array}{c}\text { Symptoms after } \\
\text { extractions of third } \\
\text { molars (examination 3) }\end{array}$} \\
\hline & $\begin{array}{l}\text { Intensity } \\
\text { of Pain in } \\
\text { TMJ (VAS } \\
\text { scale) }\end{array}$ & $\begin{array}{l}\text { Acustic } \\
\text { symptoms } \\
\text { in TMJ }\end{array}$ & $\begin{array}{l}\text { Intensity } \\
\text { of Pain in } \\
\text { TMJ (VAS } \\
\text { scale) }\end{array}$ & $\begin{array}{l}\text { Acustic } \\
\text { symptoms } \\
\text { in TMJ }\end{array}$ & $\begin{array}{l}\text { Intensity } \\
\text { pain in } \\
\text { TMJ (VAS } \\
\text { scale) }\end{array}$ & $\begin{array}{l}\text { Acustic } \\
\text { symptoms } \\
\text { In TMJ }\end{array}$ \\
\hline 1 & 7 & $\begin{array}{c}\text { Bilateral } \\
\text { clicks }\end{array}$ & 5 & $\begin{array}{c}\text { Bilateral } \\
\text { clicks }\end{array}$ & 2 & No clicks \\
\hline 2 & 5 & $\begin{array}{l}\text { Right side } \\
\text { clicks }\end{array}$ & 4 & $\begin{array}{l}\text { Right side } \\
\text { clicks }\end{array}$ & 1 & No clicks \\
\hline 3 & 3 & No clicks & 1 & No clicks & 0 & No clicks \\
\hline 4 & 6 & $\begin{array}{l}\text { Right side } \\
\text { cliks }\end{array}$ & 3 & $\begin{array}{l}\text { Right side } \\
\text { clicks }\end{array}$ & 1 & No clicks \\
\hline 5 & 3 & No clicks & 1 & No clicks & 0 & No clicks \\
\hline 6 & 5 & $\begin{array}{l}\text { Right side } \\
\text { clicks }\end{array}$ & 4 & $\begin{array}{l}\text { Left side } \\
\text { clicks }\end{array}$ & 2 & No clicks \\
\hline 7 & 5 & $\begin{array}{l}\text { Right side } \\
\text { clicks }\end{array}$ & 3 & No clicks & 1 & No clicks \\
\hline 8 & 4 & No clicks & 2 & No clicks & 1 & No clicks \\
\hline 9 & 8 & $\begin{array}{c}\text { Bilateral } \\
\text { clicks }\end{array}$ & 6 & $\begin{array}{c}\text { Bilateral } \\
\text { clicks }\end{array}$ & 3 & No clicks \\
\hline 10 & 2 & No clicks & 2 & No clicks & 0 & No clicks \\
\hline
\end{tabular}

Chi-square ANOVA $=19,54 \mathrm{p}<0,001$

Table 2. Results of statistical analysis of correlation between symptoms in patients before and after extraction of mandibular third molars

\begin{tabular}{|c|c|c|c|c|c|}
\hline \multicolumn{2}{|c|}{$\begin{array}{l}\text { Symptoms } \\
\text { before treatment } \\
\text { (examination 1) }\end{array}$} & \multicolumn{2}{|c|}{$\begin{array}{l}\text { Symptoms after } \\
\text { treatment with silicone } \\
\text { occlusal device } \\
\text { and ionotherapy } \\
\text { (examination 2) }\end{array}$} & \multicolumn{2}{|c|}{$\begin{array}{c}\text { Symptoms after } \\
\text { extractions of third } \\
\text { molars (examination 3) }\end{array}$} \\
\hline $\begin{array}{l}\text { Intensity of } \\
\text { Pain in TMJ } \\
\text { (VAS scale)- } \\
\text { median }\end{array}$ & $\begin{array}{l}\text { Amount } \\
\text { of patients } \\
\text { with clicks } \\
\text { in TMJ }\end{array}$ & $\begin{array}{l}\text { Intensity of } \\
\text { Pain in TMJ } \\
\text { (VAS scale)- } \\
\text { median }\end{array}$ & $\begin{array}{l}\text { Amount } \\
\text { of patients } \\
\text { with clicks } \\
\text { in TMJ }\end{array}$ & $\begin{array}{l}\text { Intensity of } \\
\text { Pain in TMJ } \\
\text { (VAS scale)- } \\
\text { median }\end{array}$ & $\begin{array}{l}\text { Amount } \\
\text { of patients } \\
\text { with clicks } \\
\text { in TMJ }\end{array}$ \\
\hline $5^{\mathrm{a}}$ & $\sigma^{c}$ & $3^{a, b}$ & $5^{d}$ & $1^{\mathrm{b}}$ & $0^{c, d}$ \\
\hline
\end{tabular}

${ }^{\mathrm{a}} \mathrm{Z}-2.67 ; \mathrm{p}<0.01 ; \quad{ }^{\mathrm{b}} \mathrm{Z}-2.80 ; \mathrm{p}<0.01 ; \quad{ }^{\mathrm{c}} \mathrm{Q}-10.33 ; \mathrm{p}<0.01 ; \quad{ }^{\mathrm{d}} \mathrm{Q}-8.40 ; \mathrm{p}<0.05$

Pain intensity in the TMJ before treatment (examination 1) on the VAS scale ranged between 2-8, median - 5. After treatment with a silicone occlusal device and ionotherapy with Profenid gel (examination 2), the VAS equaled 1-5, median 3 , and 2 years after extraction (examination 3), the VAS was $0-3$, median -1 . The differences noted in pain intensity were statistically significant (Friedman test Chi square ANOVA $=19.54 \mathrm{p}<0,001$ ) (Tab. 1). The differences in pain intensity in the $\mathrm{TMJ}$ in examinations 1 vs. $2 \mathrm{Z}=2.67$; $\mathrm{p}<0.01$, and examinations 2 vs. $3 \mathrm{Z}=2.80 ; \mathrm{p}<0.01$ (Wilcoxon test) (Tab. 2).

Some patients had acoustic symptoms (so-called clicks) accompanied by TMJ parafunctions. Clicks before treatment were present in 6 patients, after treatment with a silicone occlusal device and ionotherapy with Profenid gel - in 5 patients, while 2 years after extraction of impacted teeth the clicks disappeared. Differences in the presence of clicks analysed with the Q-Cochran test were statistically significant between examinations 1 and $3(\mathrm{Q}=10.33$; $\mathrm{p}<0.01)$, as well as examinations 2 and $3(\mathrm{Q}=8.40 ; \mathrm{p}<0.05)$ (Tab. 2). All patients reported their attempts aimed at eliminating parafunctions were unsuccessful. There were no patients with systemic diseases or were being treated by physicians of other specialties. 


\section{DISCUSSION}

Kleinrok et al. [7] indicate that pain radiating from mandibular muscles concerns the upper half of face and can involve the upper lateral teeth maxillary sinus, eyeball and orbits. They also emphasize that chronic headaches, TMJ aches and acoustic symptoms are manifestations of craniomandibular disorders which often induces the patients to consult a physician. It was found that headaches concerned $60 \%$ of the treated population, and in $18-20 \%$ they could be related to parafunctions and $10-25 \%$ to TMJ clicks.

An impacted third molar is usually asymptomatic and the lack of alveolar arch can be overlooked on examination of the oral cavity. There are cases when impacting is connecting with pain, for example, Romoli et al. [8] emphasize the connection between headache and impacted maxillary third molars. The patients were treated by physicians of other specialties who did not perform radiological examinations in order to demonstrate impacted teeth. Finally, in one of the patients who had complained of headache for 11 years, extraction of the upper third molar caused complete resolution of pain. Similar conclusions were drawn by Lunardon et al. [9] who examined 785 patients with headaches. In 158 patients, extraction of the upper molar had a favourable effect on treatment. According to Janas at al. [3], positive results of headache treatment were obtained in 32 patients following surgical extraction of upper third molars. These disorders may be taken into consideration in headache pathogenesis as a contributing factor.

Huang et al. [10] examined 35,479 patients aged 15-20 who were selected from a group of 241,074 persons due to continuity of their dental care for successive years. The quoted authors found a $0.05 \%$ higher risk of occurrence of craniomandibular disorders in patients after third molars extractions within 5 years of follow-up, compared with patients whose teeth were not extracted. In this group, however, symptoms dysfunction were not examined before extraction. These authors wrote that one of main risk factors of TMD was female gender, which was confirmed by other authors $[3,4,11]$. According to Grzesiak-Janas et al. [12], completely impacted third molars often occur in the mandible, and the majority of surgical interventions due to third molar impaction are performed in women. The presented study involved only females.

According to Szyperska at al. [4] based clinical observations of 120 patients impacted third molars caused sudden pains without any reason during opening and clenching of jaws. This was attributed to the lack of space for eruption of teeth 18 and 28, and also their abnormal vestibular position, causing a mechanical obstacle for lower jaw movement and lack of space for temporal muscle fascicle, leading to the occurrence of clicks, frictions, noises, and restricted movement of the mandible. After extractions, the pain complaints subsided, and acoustic symptoms which occurred in 120 patients resolved completely in 97 of them. Own results were similar as far as decrease in the intensity of pain was concerned, and the disappearance of clicks after extraction of impacted mandibular third molars.

Lewandowski and Wybieralski [13] found that some illnesses of teeth, pain in the oral cavity and jaw bones did not occur in the diseased area, but in a distant region. These authors emphasize the necessity of knowledge about dental illnesses as well as the ways of pain transmission, which can determine their cause and lead to faster diagnosis.
The basic principle for the treatment of craniomandibular disorders is controlling parafunctions. It is also important to fight stress and learn how to deal with stressful situations because stress, especially chronic stress, is one of the main causes of habitual lower jaw parafunctions. It also causes increased muscle tension. Local causal treatment consists in reconstruction of normal intra-articular conditions and correct craniomandibular muscles activity [7]. Lack of complete regression of pain complaints can be explain by parafunctions.

\section{CONCLUSIONS}

The results of the study show that extraction of mandibular third molars could cause regression of some symptoms of craniomandibular disorders. It is important to continue the research on a more numerous sample.

\section{REFERENCES}

1. Litko M, Piórkowska-Skrabucha B, Czelej-Piszcz E. Dysfunkcje narządu żucia u pacjentów poniżej 18 roku życia w materiale Pracowni Zaburzeń Czynnościowych Narządu Żucia Akademii Medycznej w Lublinie [Dysfunction of the masticatory system in patients aged under 18 in material from the laboratory for Masticatory System Functional Disorders of Lublin Medical University]. Czas Stomatol. 2007; LX(2): 119-127 (in Polish).

2. Kitai N, Takada K, Yasuda Y, Verdonck A, Carels C. Pain and other cardinal TMJ dysfunction symtoms: a longitudinal survey of Japanese female adolescents. J Oral Rehabil. 1997; 24(10): 741-748.

3. Janas A, Grzesiak-Janas G. Występowanie bólu głowy związane z zatrzymanymi trzecimi zębami trzonowymi w szczęce [Occurrence of headache related with third molar teeth retained in the mandible]. Dental Forum 2006; XXXIV(1): 63-65.

4. Szyperska AM, Zielińska K, Janas A. Zatrzymane górne zęby mądrości przyczyna zaburzeń funkcji żucia [Retained upper wisdom teeth as the cause of masticatory function disorders]. Poradnik Stomatologiczny 2009; IX(12): 441-443.

5. Panek H, Mankiewicz M. Wpływ trzecich trzonowców na częstość występowania dysfunkcji stawów skroniowo-żuchwowych u młodocianych [Effect of third molar teeth on the frequency of occurrence of temporomandibular joint dysfunction in an under-age population]. PROT STOM. 2005; LV(5): 350-356.

6. Łangowska-Adamczyk H, Drugacz J, Niedzielska I. Zatrzymane trzecie zęby trzonowe w materiale II Katedry I Kliniki Chirurgii SzczękowoTwarzowej Śl.AM W Katowicach [Retained third molar teeth in material of the Chair and Clinic for Maxillo-Facial Surgery at the Silesian Medical University in Katowice]. Czas Stomatol. 1995; 5: 324-329 (in Polish).

7. Kleinrok M. Bólowe i bezbólowe objawy związane z zaburzeniem czynności układu ruchowego narządu żucia oraz zasady rozpoznawania i leczenia tych zaburzeń [Pain and painless symptoms related with disorders in the motor system of the masticatory organ, principles of diagnosing and treatment of these disorders]. Terapia 2004; 10: 19-27 (in Polish).

8. Romoli M, Cudia G. Cluster hedeache due to an impacted superior wisdom tooth: case report. Headache 1988; 28(2): 135-136.

9. Lunardon M, Barolin G. Odontogenic (contamitant) etiology of headache. Vien Med Wocheschr. 1997; 147(15): 365-368.

10. Huang GJ, Rue TC. Thrid molar extraction as a risk factor for temporomandibular disorder. J Am Dent Assoc. 2006; 137(11): 1547-1554.

11. Huang GJ, Le Resche L, Critchlow CW, Martin MD, Drangsholt MT. Risk factors for diagnostic subgroups of painful temporomandibular disorders (TMD). J Dent Res. 2002;81: 284-288.

12. Grzesiak-Janas G, Ratajek-Gruda M, Janas A. Całkowicie zatrzymane trzecie trzonowce w materiale własnym [Totally retained third molars based on own material]. Dental Forum 2007; XXXV(1): 27-30 (in Polish).

13. Lewandowski L, Wybieralski J. Występowanie otalgii dentogennej i stomatogennej w chorobach zębów jamy ustnej i szczęk [Occurrence of dentogenic and stomatogenic otalgia in dental diseases of the oral cavity and jaws]. Otolaryng Pol. 1982; XXXVI(506): 301-304 (in Polish). 